\title{
研究課題別事後評価結果
}

1. 研究課題名

超臨界流体を用いた反応の制御と新反応の開拓

2. 研究代表者名及び主たる研究参加者名（研究機関名・職名は研究参加期間終了時点）

研究代表者梶本 興亜 京都大学大学院理学研究科 教授

主たる研究参加者 中原 勝 京都大学化学研究所 教授

新田 友茂 大阪大学大学院基礎工学研究科 教授

永見 憲三 サントリー酒類研究所 部長

吉田 潤一 京都大学大学院工学研究科 教授(平成 12 年 4 月～)

3. 研究内容及び成果

$3-1$ 研究の基本構想亡展開

超臨界流体は、臨界点直上の温度・圧力を持つ状態にある。臨界点では気液の相転移が消失し、液体と気体 の双方の性質を併せ持った流体は、大きな密度摇らぎを示す。ここに溶質分子を入れると、引力によってその 周囲に溶媒分子が集まり、密度増加を伴う大きな溶媒和（クラスタリングあるいは局所密度増大とも呼ばれ

る）が起こる。

超臨界流体は、化学反応のための新しい溶媒として注目されているが、反応分子に対する上述のような溶媒 和が、化学反応の速度に大きく関係していることが分かってきた。本研究課題は、超臨界流体溶媒中の溶媒和 構造を解明し、溶媒和の制御を通して化学反応をコントロールすることを目標とした。具体的には 5 つのグル 一プ (京大院理・梶本興亜教授を研究代表者とし、共同研究者として京大化研・中原勝教授、阪大院基礎工 • 新田友茂教授による基礎的検討グループ、及び京大院工・吉田潤一教授、サントリー基礎研・永見憲三部長ら による応用検討グループを配した）が互いに協力しながら、以下の4つの課題について取り組んだ。

(1) 超臨界流体の溶媒和構造の解明

(2) 超臨界流体の反応基礎過程

( 3 ) 超臨界水中での化学反応

(4) 超臨界水研究用実験装置の開発

$3-2$ 研究成果

$3-2-1$ 超臨界流体の溶媒和構造の解明（梶本・中原グループ）

超臨界流体に溶解させた反応分子の周囲に溶媒分子がどのようにクラスターを作るかを、溶質及び溶媒流体 を変えて、温度と密度の関数として解明することとし、高温の超臨界水と常温付近に臨界点を持つ $\mathrm{CO}_{2} や$ $\mathrm{CF}_{3} \mathrm{H}$ について比較した。具体的にはp-二トロアニリンを溶質の代表として、そのスペクトルシフトの温度 ・ 密度依存性を $\mathrm{CF}_{3} \mathrm{H}$ と水で測定し比較した。その結果、常温超臨界流体の場合は溶媒－溶質間相互作用がクラ スターの生成に重要な役割を果たすのに対して、超臨界水では溶媒－溶媒間の相互作用、言い換えれば、溶媒 自体の臨界密度摇らぎが大きく寄与していることが判明し、溶媒和の起源についての典型例を示すことができ た。

水の異常な特性の多くは水素結合に由来する。従つて超臨界水の性質もまた、その温度密度条件において水 素結合がどの程度残つているかに影響される。高温高圧 N M Rを用いて超臨界水のプロトンの化学シフトを測 定した結果、温度の上昇及び密度の減少に従って水素結合は弱くなるが、臨界点近傍でも通常の 1 / 4の水素 結合が残つていることが判明した。水素結合ネットワークの強さを知る上で、NMRのT 2 緩和速度を用いて回 転拡散を評価した結果、化学シフトによる水素結合の強さの傾向と非常によい一致が見られた。

\section{$3-2-2$ 超臨界流体中の基礎過程（梶本グループ）}

超臨界流体中での溶媒和が反応に関する基礎過程にどのような影響を与えているかを検証した。超臨界流 体中の溶質分子の特定の振動モードに振動エネルギーを与え、これがどのように分子内に分配され（分子内工 ネルギー再分配、IVR）、あるいは外界の溶媒分子に散冕（分子間エネルギー移動、VET）されていくかを、 超高速レーザーシステムを用いて測定した。

超臨界流体中での分子間エネルギー移動の測定は、アズレン分子の蛍光スペクトルの経時変化によって追跡 した。エネルギー散冕速度は、流体の密度増加とともに早くなるが、その増加の傾向は流体のバルク密度では 
なく、溶媒和数の変化を反映していることが判明した。

一方分子内の工ネルギー再分配が外界の分子によって影響されるかについては超臨界流体Xe中での密度依 存性を調べた結果、そのIVR速度が明らかに流体の密度に依存することが判明した。

3-2 - 3 超臨界水中の化学反応（梶本・中原・永見・吉田グループ）

超臨界水は水素結合が通常の水の1／4程度あり、まだかなりの極性を持った溶媒である。更に密度変化に よってこの極性を調整することができることで、超臨界水中での多くの反応例が世界各国から報告されてい る。しかしながら、定量的で㛜密な実験が非常に少ない。このプロジェクトでは、物理有機化学的視点に立っ て超臨界水中での反応を解析することを目標とした。

最初に取り上げた反応は、エステルの加水分解である。超臨界水がエステル結合を容易に切断することは分 かっているが、その機構がイオン的であるかラジカル的であるか、 $\mathrm{H}^{+}$とOH あるいは $\mathrm{H}_{2} \mathrm{O}$ のどれがイナーシ アかについてはこれまで不明であった。反応速度の密度依存性を詳細に検討することによって、この反応が $\mathrm{OH}^{-}$の触媒作用によって進行することが明らかになった。また、その密度依存性が、誘電率の変化を反映す ることも証明された。

超臨界水中での反応は一般にステンレス容器を用いてバッチ方式で行われることが多く、水中の残存酸素の 影響や反応器の器壁効果を受けることが多い。このような効果を反応の本質と見誤る例も非常に多い。本研究 では、水の溶存酸素を除くとともに、石英容器を反応器として用いることで、水自身の本質的な反応を追跡し た。その成果の一つとして、超臨界のみ（無触媒）でエタノールから水素とアセトアルデヒドが生成する反応 を見出した。（特許出願）

この反応のメカニズムとして、中性の水分子が触媒のような形で反応を助けていることが予想された。

3-2-4 超臨界水実験用装置の開発（梶本・中原グループ）

超臨界水の研究は、400 C、300気圧の水に耐える装置の開発が必須である。適切な装置が無いために超臨 界水の詳細な研究が遅れているとも言える。本プロジェクトの重要な課題としてこのような実験装置の開発を 挙げることが出来る。

超臨界水の溶媒和構造などの実験のためには、UVスペクトルを測定するためのセルを必要とする。流通型 で容易に超臨界水を生成できるコンパクトな装置の設計に成功し、通常のUVスペクトロメーターの測定室に 取付た装置を完成させた。（特許出願）

超臨界水化学反応の実験において重要なことは、生成物の的確な同定と同時に、反応温度の確定である。 「流通型高温高圧NMR装置」は超臨界水反応を調べるための究極の実験装置と言え、本プロジェクトの後半 は、この装置の立ち上げに注力した。NMR試料管の材質と形状の選択、フロ一管と試料管の接合部、温度維 持装置などの完成を待って、最終年度に装置を組み上げて、プロトンシグナルの観測に成功した。この装置は 今後の超臨界水反応の研究に大きな力を発揮すると期待される。（特許出願）

4. 事後評価結果

4 - 1. 外部発表(論文、口頭発表等)、特許、研究を通じての新たな知見の取得等の研究成果の状況

梶本グループの研究は、近年着目されてきた超臨界流体の基礎を研究したもので、梶本教授や共同研究者ら の物理化学的基礎力と、特に網田氏の高圧実験技術によって今まで不明であった超臨界水の実態が明らかとな ってきた。以下重要な成果について述べる。

4-1-1 超臨界流体中の溶媒和の機構や振動工ネルギー移動の解明

(1) M.Matsubayashi,N.Nakao,M.Nakahara,J.Chem.Phys.,114,4107(2001) 超臨界状態における水素結合の強さをNMRを用いて回転拡散で評価した。

(2) K.Sekiguchi,A.Shimojima,O.Kajimoto,Chem.Phys.Lett.,356,64(2002) 分子内の工ネルギー再分配について、超臨界X e 中での研究で密度依存することを見出した研究。国 際的にも高い評価を得た。

4-1-2 超臨界流体中の反応の直接観測

( 3 ) F.Amita,K.Okada,H.Oka,O.kajimoto, Rev.Sci.Instrum.,72,3605(2001) 流通型高温高圧NMRプローブの開発（世界初）

4-1-3 超臨界水によるH $\mathrm{H}_{2}$ ガスの製造

(4) T.Arita,K.Nakahara,K.Nagami,O.Kajimoto, Tetrahedron.Lett., in press(2002) 
無触媒でアルコールから $\mathrm{H}_{2}$ ガスの生成を見た。水が触媒的に関与していることが計算 からも裏づけさ れた。

$4-2$. 得られた研究成果の科学技術への貢献

とかく現象が先行している超臨界流体の利用であるが、本研究によってその基礎化学が確立してきたことは 応用サイドに大きな推進力を与えたことになる。また期中に開発された超臨界流体型NMR装置は、今後の化 学反応解析に多いに役立つものである。

$4-3$. その他の特記事項

特筆すべき事として、研究実施に加えて、CREST支援の下に開かれた研究会や学会が大きな役割を果た し、日本及び世界の超臨界流体基礎研究の潮流を作つたことである。国内的には二度にわたる研究会を開催し 国内の超臨界流体基礎研究を指向する殆どの研究者が集まって、活発な討論が行われた。国際的には、八ワイ における超臨界基礎研究のシンポジウムと、京都における「Informal Meeting on the Fundamental Aspects of Supercritical Fluids」を開催し、今後の国際会議をリードする立場を確立した。

$\leq<$ 単一分子トップ

This page updated on September 12, 2003

Copyright(C)2003 Japan Science and Technology_ Corporation 